\title{
Policies and Practices of Virtual Communication during Social Isolation of COVID-19
}

\author{
Lilia Raycheva*, Neli Velinova, Nadezhda Miteva, Mariyan Tomov \\ The St. Kliment Ohridski Sofia University, Bulgaria
}

\begin{abstract}
The COVID-19 pandemic has led to drastic changes in people's lifestyle around the world, incl. those related to the natural way in which individuals interact and communicate. The topic of virtual communication in the context of social isolation during the spread of the new corona virus strain (SARS-CoV-2) and its associated disease COVID-19 is an extremely important scientific problem with paradigmatic dimensions and fundamental consequences for society. As a technologically mediated way of communication, it proved that during a pandemic, the virtual communication is the only alternative to traditional face-to-face communication, and its use was inevitable to partially or completely overcome the social restrictions imposed. In order to examine some of the effects of virtual communication during the social isolation, an academic research team from the Faculty of Journalism and Mass Communication at The St. Kliment Ohridsky Sofia University of Bulgaria undertook a study in the declared two month's period (13.03.-13.05.2020) of the state of national emergency in the country. The researchers conducted a three-folded study: on the sociological polls and the media coverage during the pandemics; on the impacts of virtual communication during the social isolation; and on the activities of the telecommunication industry in Bulgaria. The results of the effects of virtual communication in social isolation were indicative.
\end{abstract}

Keywords: COVID-19, virtual communication, social isolation, media, telecommunications

\section{Introduction}

The quick spread of COVID-19 found the world unprepared psychologically, economically, medically and socially. It has resulted in a unique and unconventional lockdown for a great percentage of the Earth's population. Citizens have changed their daily lives; governments had to become more flexible, systemic to protect the health of their citizens; companies were ordered to prioritize safety and well-being above profits, whilst their value chains were being turned upside down. The World Health Organization (WHO) has declared the corona virus disease in 2019-2020 to be a pandemic, as well as a critical public health emergency of international concern (PHEIC). Throughout the pandemic period, the WHO has periodically issued a number of recommendations to address the global situation. Thus, in March 2020, at a joint virtual press conference, the UN, the UNICEF and the WHO announced a coordinated global plan to combat COVID-19, with the aim of helping the most financially vulnerable countries (Global, 2020).

Between early March and the end of May, the European Commission (EC) alone adopted 291 decisions and other acts on COVID-19. They reflected the urgency and the dramatic nature of the situation, as well as the speed at which the EC had to readjust from delivering on long-term objectives to immediate crisis management. The European Commission's revised Work Program for 2020 stated, that what started with isolated cases quickly turned into a public health crisis, an economic shock of unprecedented scale and a pandemic of global and tragic proportions (Communication, 2020).

The aftermath of the gradually easing lockdown in Europe is not problem-free. That is why it makes sense to consider alternative ways to compensate for the limitations of these social challenges through alternative forms of communication. Merit deserves those that technologically enable people to overcome the strain of isolation.

In the countries of the European Union, the ban on crossing borders and restrictions on movement is now and then being upheld, but the consequences of staying at home for several months might have a lasting effect on countries 
and their populations, which needs to be studied. The threat to health, combined with economic insecurity and forced social isolation, has potentially dangerous consequences for the individual. Lack of social activity (interpersonal communication, participation in public life, social and economic employment) is among the leading reasons for the deterioration of the mental and emotional state of the affected people. That is why urgent introduction of modern technology-based solutions to promote an active and healthy lifestyle is needed. Among them is virtual communication as a technologically mediated way of communication. During the pandemic, it proved to be the only alternative to traditional face-to-face communication, and its use was inevitable to partially or completely overcome the restrictions imposed.

Of significant importance in research topics on the essence of COVID-19 is the societal segment. The pandemic exposed people to psychological distress, fatigue, occupational burnout, fear, combined with the economic insecurity and the forced social isolation, has potentially dangerous consequences for the individual (Venkatashiva \& Gupta, 2020). Therefore it is of utmost importance that effective communication should be ensured at workplace, in families and at communities. In light of the COVID-19 crisis it is significant to assess how information forms and sources influence the public's information-seeking behaviour and the perception of government's crisis response strategies during the pandemic (Moreno et al., 2020; Zarocostas, 2020; CuanBaltazar et al. (2020). The ECLB-COVID-19 consortium of researchers of the effects of social isolation on the health and mental state of people living on four continents recommended the urgent introduction of modern technology-based solutions to promote an active and healthy lifestyle. Among them was virtual communication as a technologically mediated way of communication. During a pandemic, it proved to be the only alternative to traditional face-to-face communication, and its use was inevitable to partially or completely overcome the social restrictions imposed (Ammar, 2020).

Bulgaria reacted relatively quickly and efficiently at the institutional level to the public health emergency announced by the World Health Organization regarding the disease COVID-19. On February 26, 2020, by order of the Prime Minister, a National Operational Headquarters was established. Among its responsibilities were to organize, coordinate and monitor all actions of the competent authorities in relation to the prevention of the spread of COVID-19, as well as to collect, summarize and analyse all information on the development of the situation in order to inform the media and the public (COVID-19, 2020). The National Assembly passed a law on measures and actions during the state of national emergency, declared by its decision of March 13, 2020 (Law, 2020). It lasted exactly two months - until 13.05.2020, when replaced by an emergency until 15.07.2020.

\section{Aim and Research Methods}

Undoubtedly, the COVID'19 pandemic will have a long-lasting influence on how individuals, employees, customers and organizations will work, produce and interact with each other. The transformations of human contacts during the pandemic towards intensive e-communication in a number of social spheres, institutions, communities and even individuals have fundamental scientific importance because it caused and continues to cause a change of paradigms, concepts, social practices and policies.

Though a plethora of research topics would be well fit for examining the pandemics in general, the aim of the undertaken research is to focus on a fundamentally specific societal objectives: to track the effects of virtual communication in the situation of social isolation in Bulgaria and to utilize the structured and analysed information for policy support of decision makers, academia, media, telecommunications, general publics, and private sector in possible future crises, similar with the present one.

The study aims at answering three research questions, concerning the COVID-19 spread in Bulgaria:

- What is the level of adaptability and the way in which respondents coped socially during the isolation associated with the corona virus pandemic? 
- What is the level of trust in media of the respondents in the context of "infodemia"?

- How virtual communication in the conditions of social isolation affects the telecom industry?

The study is interdisciplinary and it uses mixed research methods, among them:

- Comparative analysis of the derived data from sociological surveys, regulatory frameworks and media and telecommunications practices;

- Quantitative research, conducted via an individual direct poll. The number of the respondents is limited to 185 persons ( $\mathrm{N}=185)$ of various age, gender, educational level, and employment were asked 28 questions.

In addition, cross-combining technique for data collection and analysis was applied in order to compensate some of the inherent limitations.

\section{Results}

\section{Sociological Polls and Media Coverage during the Pandemics}

The national representative surveys of Alpha Research (Reflection, 2020), Trend (Trend, 2020), and Gallup International (Mass, 2020) sociological agencies, conducted during the state of national emergency (13.03.13.05.2020) showed an overall acceptance and support by the publics for the health quarantine measures and restrictions. Critical sentiments were present only towards the still unclear economic measures. Most of the participants answered, that increased amount of time spent at home had a negative effect on their mental and physical health. Many Bulgarians realized that the fight against COVID-19 would take a long time until the return to their normal lifestyle.

Although the behaviour of the media was not tackled in these sociological surveys, the practices have shown their unprecedented activity in covering the state of national emergency and the information that has been promptly reported by the National Operational Headquarters and the institutions involved in controlling of the spontaneous extreme situation. The declared state of national emergency and the accompanying restrictive measures unequivocally displayed that the media environment with its timely and persistent information about the development of the disease was crucial for the normal functioning of the economy and the society. The media also had to readjust ad hoc because they had the responsibility to participate in the national management of the pandemic and in alleviating the stress in society caused by the emergency profound changes.

The point of the public debate in the media about the corona virus, however, was not so much to challenge the constitutional right of the executive power to vital measures during the pandemic, nor to instruct people on how and whether to comply with the undertaken measures. The important issue was to protect people from "infodemia", i.e. from the disproportion in their access to other important information, in order to they do not fall prey to unreliable messages and rumours that spread mostly via social networks.

\section{Virtual Communication during the Social Isolation}

In order to examine some of the effects of virtual communication in the conditions of social isolation, an academic team from the Faculty of Journalism and Mass Communication at The St. Kliment Ohridski Sofia University undertook a survey during the two-month's period of the state of national emergency in the country (13.03.202013.05.2020). Among the objectives of the survey was to monitor the level of adaptability and the way in which respondents coped socially during the isolation associated with the corona virus pandemic (Raycheva et al., 2020). 
More than $86 \%$ of the respondents were satisfied with the opportunity to work and/or study online. $65 \%$ of the interviewees gave positive answer to the question whether employers/teachers support distance work. Although $67 \%$ claimed that they were not worried of losing their job or of education failure, $59 \%$ felt that the pandemic situation negatively affected their work. The prevailing opinion of the respondents was that dealing with the situation, which changed the status quo, requires solidarity, empathy and care for the weaker and riskier groups of our society. Thus they saw the crisis as an opportunity for the Bulgarian society to look at these problems in depth.

Another objective of the survey was to study which channels of information the interviewees had used. $78 \%$ of all respondents pointed out the traditional media as the most used information source during the COVID-19. The prevailing part of them stated that they prefer to watch television, then - listen to the radio. Most of the interviewees specified that combine their sources of information, as they want to compare the data with more than one media channel.

The third objective of the survey was to analyse the level of trust in traditional, online, social networks, social media) of the participants in the survey. More than half of the respondents - 65.9\% - were adamant that they trusted the traditional media at most. Again, television was the preferred medium, followed by radio $-12.2 \%$, and press - 9.8\%. Merit deserved the comparison between consumption (62.2\%) and trust (23.7\%) in the online news agencies and websites. Similar was the situation with the social networks. Close to half of all respondents $(48.1 \%)$ were regular users of Facebook, Tweeter, Instagram, Linkdin, etc., but only $12.4 \%$ stated that they trusted social networks. Although only 9.2\% used as main source of information social media (blogs, YouTube, etc.), the trust in them was higher than in social networks (14.5\%).

The most unpleasant impression for some of the respondents was the media search for sensations at any cost, which often led to incitement to hatred - to the church, to the Roma, to the Bulgarian guest workers returning from abroad, etc. By doing so media helped to instil fear in society. Regarding the psychological impacts, the largest number of respondents - 59.7\% answered that the over saturation with information about COVID-19 depressed them. $16 \%$ claimed that the information was contradictory and confused them. Only a smaller share (13.4\%) was of the opinion that the information was timely and useful and that they felt informed.

Most of the respondents were impressed by the level of mobilization of the Bulgarian media and by their responsiveness to the emergency. Among the negative opinions about the media coverage of COVID-19 was the pyramidal paramilitary model of information, as well as the lack of criticism of the official information and the limited debate with various opinions about the corona virus. Some of the respondents explained that the media concentrated mainly on the spread of the virus and did not pay enough attention to other factors following the pandemic, such as the economic challenges in Bulgaria and throughout the world. When asked how they assessed the media coverage of the COVID-19 pandemic, the largest percentage of the respondents claimed that negative news which shocked the people (51.6\%) prevailed. For $46.2 \%$ of the interviewees, the media paid too much attention to the situation with the corona virus and became intrusive.

\section{Challenges and Opportunities Facing Telecommunications Industry}

For many sectors in the economy (e.g. tourism, restaurant services, retail trade, transport and logistics, media, entertainment industry and film production) the period of forcibly imposed anti-epidemic measures had adverse effects such as temporary or even permanent termination of activities, lay-offs and furloughs, financial losses, reorganization of the supply and distribution chains, filing for bankruptcy. However, for the telecommunications industry in Bulgaria these measures had just the opposite effect.

From the very first days of social isolation, mobile operators and internet providers enjoyed peak consumption of their services and got higher income. The explanation for this was connected with the attempts to continue casual 
activities online (e.g. work and education from home, online shopping, payment of bills, medical consultations, etc.). High levels of distress in people as a result from the abrupt changes in lifestyle, as well as the ban to travel without a valid reason also contributed to overloading the capacity of transmission networks. Their services had to ensure not only the connectivity of their subscribers, but also the ability to operate the entire education system, the public administration, all digital services and the work of a huge number of people from home.

The process of adaptation of the Bulgarian mobile operators to the new situation was characterized with speed and flexibility of adapting to these changes in societal and economic life. With this regard the following dimensions of their reaction can be outlined:

- Ensuring the safety of company employees and customers and encouraging the use of existing and the development of new digital services.

Providing for additional opportunities for communication, connectivity, entertainment and education was the unifying policy of the three leading mobile operators in Bulgaria (A1, Vivacom and Telenor). Telecommunications companies used the period of forcibly imposed social isolation to promote online purchases of devices, gadgets and accessories by using mobile apps, or discounts, or gifts, or other incentives. Besides, it was a favourable period to promote their own mobile platforms for payment services of all kinds.

- Social solidarity and online security in times of isolation.

All mobile operators, in cooperation with the National Operational Headquarters, maintained free of charge the mobile application ViruSafe. Digital services were developed to serve business clients how to run and manage work from home. In April A1 came up with a free of charge application A1 Guard for prevention of telephone fraud - first of a kind in Bulgaria (Technologies, 2020). Its release was in line with the warnings of the Ministry of Interior for activating telephone fraudsters in the conditions of social isolation.

- Donation during quarantine - shared responsibility.

Telecommunications companies in Bulgaria started wide-scale donations activity during the state of national emergency, built on the principle of shared responsibility. Consumers "invested" funds in the company, which in turn "shared" the gains with the society to overcome the crisis. The telecoms were very active in the direct assistance to health authorities and hospitals to effectively deal with the corona virus infection and support for schools and students in adapting to distance learning from home. The overall amount of the reported donations by the telecommunications companies to fight against COVID-19 exceeded 1 mln BGN (1 320000 BGN) (A1, Telenor, Vivacom, 2020).

During the state of national emergency, the telecommunications companies operated under the increased control of the Communications Regulation Commission (CRC) - the regulatory body for postal services and electronics communications and in the shadow of the legal possibility to use mobile data for uncontrolled monitoring of the publics. The CRC monitored with anxiety the functioning of transmission networks and called for reasonable usage of capacities and traffic prioritization in order to avoid possible collapse (The Communications, 2020).

\section{Conclusion}

Dealing with the pandemic not only in medical and economic, but also in social and communication terms posed significant challenges to the institutions and the population in Bulgaria during the state of national emergency. In this sudden and unprecedented situation, the crisis response systems and the capacity to make balanced decisions were subjected to a kind of stress test in a real situation. In order to limit the spread of the corona virus in Bulgaria, the state institutions issued a number of measures and recommendations to citizens, companies and organizations. The traditional understandings of labour, physical communication, working space had to transform ad hoc. The 
means of virtual communication, including specialized training software, "saved" students from completing the school year on a regular basis. The so-called "home office" became increasingly important and popular. In this new extraordinary situation, people experienced the professional deficits in the field of digital infrastructure and connectivity at national and international level.

Slowing viral transmission during pandemics caused significant shifts in individual and collective behaviour. The crisis required large-scale communication change and placed significant psychological burdens on individuals and organizational difficulties to institutions and businesses.

The research was based on the idea that insights from the social and behavioural sciences can be used to help align human virtual communication with the recommendations of the epidemiologists and public health experts during the social isolation. Thus, answering the three research questions, the study of the virtual communication in the social isolation of the two-month state of national emergency regarding COVID-19 in Bulgaria, led to some major conclusions.

Firstly, the restructuring of the communication in the situation of social isolation caused a variety of challenges to the adaptability and the way in which people coped socially during the quarantine associated with the corona virus pandemic. Although according to the sociological polls the broad publics showed an overall acceptance and support for the health quarantine measures and restrictions, later on the burden of the economic measures and the increased amount of time spent at home impacted negatively the mental and physical health of the people.

Secondly, the imposed by Government decree social isolation caused an increase in the demand for timely information about the COVID-19. The results of the survey displayed that a larger part of the population preferred traditional media, namely the public service broadcasters to follow the developments of the pandemic. Traditional media (television, radio, press) became much more trusted compared to the social networks. The results of the survey also confirmed the opinion of the media professional organizations regarding the negative effects of the "infodemia".

Thirdly, the research results showed that the period of forced social isolation provided an opportunity for the telecommunications companies to convince the society of their responsibility and solidarity.

The effects of virtual communication during the social isolation presupposed the importance of the media system and the telecommunications industry as core determinants in the social management of the processes in extraordinary situations.

Although nowadays the health system in the country is much more prepared to meet the further challenges of COVID-19, the danger of mass infection has struck again. The major part of the study is planned to be repeated in one year after declaring the state of national emergency in order to trace the developments of the social impacts of the pandemic. In crisis situations, such as the one with COVID-19, the effects of virtual communication in social isolation are indicative.

\section{Acknowledgements}

The paper has been developed within the framework of COST Action CA16226 Indoor Living Space Improvement: Smart Habitat for the Elderly (SHELD-ON) of the European Commission, supported by the research projects KP-06-COST/5-18/06/2019 and KP-06-M35/4-18/12/2019 of the National Scientific Fund of Bulgaria. 


\section{References}

Global Humanitarian Response Plan. COVID 19. United Nations coordinated appeal. United Nations. (2020, April). Retrieved from https://www.unocha.org/sites/unocha/files/Global-Humanitarian-Response-Plan-COVID19.pdf

Communication from the Commission to the European Parliament, the Council, the European Economic and Social Committee and the Committee of the Regions. Adjusted Commission Work Programme. European Commission (2020, May 27). Retrieved from https://ec.europa.eu/info/sites/info/files/cwp-2020-adjusted_en.pdf COVID-19: $\quad$ Unified $\quad$ Information $\quad$ Portal. $\quad$ (2020). Retrieved from https://webcache.googleusercontent.com/search?q=cache:WYbmUQ_RSyQJ:https://coronavirus.bg/bg/231+\&c $\mathrm{d}=8 \& \mathrm{hl}=\mathrm{en} \& \mathrm{ct}=\mathrm{clnk} \& \mathrm{gl}=\mathrm{bg}$

Venkatashiva, R.., Gupta A. Importance of Effective Communication during COVID-19 Infodemic. J Family Med Prim Care. Aug 9(8) 3793-3796. Retrieved from: https://www.ncbi.nlm.nih.gov/pmc/articles/PMC7586512/. (2020)

Moreno, Á., Fuentes-Lara, C., Navarro, C. COVID-19 Communication Management in Spain: Exploring the Effect of Information-seeking Behavior and Message Reception in Public's Evaluation. El profesional de la información, v. 29, n. 4, e290402. Retrieved from: https://doi.org/10.3145/epi.2020.jul.02. (2020)

Zarocostas, J. How to Fight an Infodemic. The Lancet, 395 (10225). Retrieved from: https://doi.org/10.1016/S0140-6736(20)30461-X (2020).

Cuan-Baltazar JY, Muñoz-Perez MJ, Robledo-Vega C, Pérez-Zepeda MF, Soto-Vega E Misinformation of COVID-19 on the Internet: Infodemiology Study JMIR Public Health Surveill 2020;6(2):e18444 doi: 10.2196/18444 Retrieved from: https://doi.org/10.2196/18444. (2020).

Ammar, A., Brach, M., Khaled, T. Effects of Home Confinement on Mental Health and Lifestyle Behaviours during the COVID-19 Outbreak: Insight from the "ECLB-COVID-19" multi countries survey [online]. Retrieved from: https://www.medrxiv.org/content/10.1101/2020.05.04.20091017v1.full.pdf+html (2020)

Law on Measures and Actions during the State of Emergency, announced by a decision of the National Assembly of March 13, 2020. State Gazette. (2020, March 28). Retrieved from https://dv.parliament.bg/DVWeb/showMaterialDV.jsp?idMat=147150

Reflection of the First Stage of the Corona Crisis Virus on the Political Ppicture in the Country. Alpha Research. (2020, May). Retrieved from https://alpharesearch.bg/post/969-otrajenie-na-purvia-etap-ot-krizata-skoronavirusa-vurhu-politicheskata-kartina-v-stranata.html

Trend: $68 \%$ of Bulgarians Are Worried about Visiting Places with Many People. Trend. (2020, May 8). Retrieved from https://novini.bg/bylgariya/obshtestvo/597366

Mass Attitudes towards the Coronavirus Situation: Signs of Normalization. Gallup International: Center for Public and Political Studies. (2020, May 20). Retrieved from https://www.gallupinternational.bg/43323/\%d0\%b0ttitudes-towards-the-coronavirus-situation/

Raycheva, L., Velinova, N., Miteva, N., Tomov, M. Impacts of Virtual Communication during Social Isolation of Covid'19. In: Karwowski, W., Ahram T., Etinger, D., Tanković N., Taiar R. (eds.) Human Systems Engineering and Design (IHSED 2020): Future Trends and Applications, September 22-24, 2020, Juraj Dobrila University of Pula, Croatia. Springer, Cham. pp: 63-68. Retrieved from: https://doi.org/10.1007/978-3-030-58282-1. (2020)

Technologies in the Fight against Telephone Fraud. Investor. (2020, April 1). Retrieved from https://www.investor.bg/telekomunikacii/457/a/tehnologiite-v-borba-s-telefonniteizmamnici-301664/

A1 donated respirators to the hospitals in Silistra, Dobrich and Montana, thanks to the people who use My A1. A1. (2020, April 27). https://www.a1.bg/medien-tsentar-informatsia-zamediite/mc/index/ma/view/infoblock_id/2744

See A1. (2020, April). Retrieved from https://www.a1.bg/medien-tsentar-informatsia-zamediite/mc/index/ma/view/infoblock_id/2744; $\quad$ Telenor $\quad$ (2020, April). Retrieved from https://www.telenor.bg/bg/news/; Vivacom $\quad$ Telenor $\quad$ (2020, April). $\quad$ Retrieved from https://www.vivacom.bg/bg/home 
The Communications Regulation Commission Recommends that Consumers Follow the Trends in Internet Traffic. Communications Regulation Commission. (2020, April 2). Retrieved from https://crc.bg/bg/novini/1304/komisiqta-zaregulirane-na-syobshteniqta-preporychva-na-potrebitelite-da-sesyobrazqt-s-tendenciite-vinternet-trafika 